\title{
Through Jevic's Mirror: Orders, Fees, and Settlements
}

\author{
By Nicholas L. Georgakopoulos*
}

After a long period of silence about reorganization law, the United States Supreme Court's Jevic opinion offered the opportunity for clarification and updating. Instead, Jevic gives a narrow holding against structured dismissals but has potent undercurrents about first-day orders, fees, and settlements.

\section{Contents}

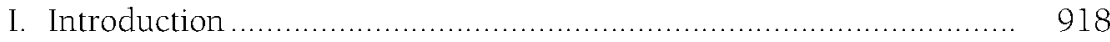

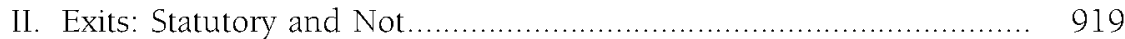

A. Plans, Conversions, and Dismissals............................. 919

B. Sub Rosa Plans Through $\S 363$ Sales................................ 920

C. Structured Dismissals ............................................. 923

III. Jevic: Facts and Opinion ........................................... 924

A. The LBO Fraudulent Transfer Claims ................................. 924

1. LBO Fraudulent Transfer Principles............................ 925

2. Unearthing the Transfer .................................... 927

3. The Subordination Remedy................................. 928

4. The Settlement ..................................................... 929

B. The Wage and Inadequate Notice (WARN Act) Claims............ 930

C. The Narrow Holding: "No" Structured Dismissals ................... 932

IV. Through the Mirror: Undercurrents and Expansions................... 934

A. First-Day Orders ................................................. 934

B. Biases About Fees ...................................................... 936

C. Settlement Propriety ............................................ 938

D. Litigating and Settling Incentives ................................... 940

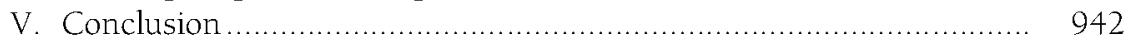

* Harold R. Woodard Professor of Law, McKinney School of Law, Indiana University. I wish to thank Jim Bailie, Dan Dooley, Sarah Harrington, Melissa Jacoby, Ken Klee, Lynn LoPucki, Stephen Lubben, Richard Posner, Gideon Schor, and Danielle Spinelli for helpful comments, Susan David deMaine for her always amazing assistance from the library, as well as indicate my gratitude for the research assistance of Alan Giffey and Omowole Omosehinmi and for the discussions with my entire Spring 2017 Reorganizations class. I urge you to send your comments to me at ngeorgak@iu.edu. 


\section{INTRODUCTION}

The world dominance of the bankruptcy practice by the United States is, in part, a result of the thick interpretation that reorganization law enjoys. ${ }^{1}$ The U.S. Supreme Court added a layer of interpretation by issuing its opinion in Jevic in March 2017. ${ }^{2}$ The lower court erred by ordering a dismissal of the bankruptcy of Jevic and approving a settlement that produced value for unsecured creditors while the priority claims of employees had not been satisfied.

Understanding Jevic, however, is not simple. The argued question eventually came to be the propriety of structured dismissals, a term describing the practice of dismissing a chapter 11 filing while retaining some consequences of bankruptcy law (as opposed to the default of restoring the previous state of affairs). ${ }^{3}$ In Jevic, the dismissal also allocated value among claimants and barred the employee creditors from waging a fraudulent transfer attack against the leveraged buyout of Jevic by its last owners. In the background is the propriety of first-day orders and of transactions (known as \& 363 sales, including settlements) that influence distributions to claimants. This article probes Jevic, revealing three undercurrents. First, the court's dicta about first-day orders and interim approvals of settlements are important for bankruptcy practice. Second, the court was not far from addressing courts' attitudes toward fees, especially legal fees; the academy has long discussed the race-to-the-top or to-the-bottom nature of the jurisdictional competition for bankruptcy filings, and the Court could have addressed that. Third, the centrality of assessing settlements that fund endeavors-litigation in Jevic's counterpoint, Iridium-leads to a discussion of the biases those produce.

The expedition to conquer Jevic begins in Part II with conventional, statutory, Code-authorized exits from reorganization: reorganization plans ("plans"), conversions to chapter 7 , and dismissals, juxtaposed to unconventional but not unusual ends by sub rosa plans through $\& 363$ sales and structured dismissals. Part III first explains the facts of Jevic - the leveraged buyout ("LBO") fraudulent

1. The only other jurisdiction with a potential claim to attract cross-border insolvency filings is the United Kingdom but it does not do so. See Oscar Couwenberg \& Stephen J. Lubben, Corporate Bankruptcy Tourists, 70 Bus. Law. 719, 740-45 (2015) (studying a sample of filings by large foreign businesses and discussing the reasons that the United Kingdom has failed to attract significant insolvency filings); see also, e.g., Patrick Fitzgerald, South Korea's Hanjin Shipping Files for U.S. Bankruptcy Protection, WaLL St. J. (Sept. 4, 2016) [archived at http://perma.cc/6PTB-7EA7]; Press Release, Cleary Gottlieb, Chilean Bus Operator in Prepackaged Bankruptcy (Dec. 17, 2014), https:/www.clearygottlieb com/news-and-insights/news-listing/chilean-bus-operator-in-prepackaged-bankruptcy65 [archived at http://perma.cc/Z4LC-5RYE] (reporting the prepackaged filing of bus operators Alsacia and Express and a prior representation of a different Chilean business by Cleary Gottlieb, electricity provider Edelnor); Bankruptcy Research Database, http://opuckilaw.ucla.edw/spreadsheet.htm [archived at https://perma.cc/S7Z2-FDVX] (accessed Apr. 20, 2017) (sort by headquarter city, scroll to "Outside the United States," screen 16-17, indicating twenty-one filings of businesses headquartered abroad totaling over thirty billion in annual sales, which do not include Hanjin, Alsacia \& Express, and Edelnor, as the database is limited to businesses that file SEC Form 10-K).

2. Czyzewski v. Jevic Holding Corp., 137 S. Ct. 973 (2017).

3. Earlier, according to the grant of certiorari, the issue was the propriety of approving settlements. Id. at 987 (Thomas, J., dissenting) ("We granted certiorari to decide "[w] hether a bankruptcy court may authorize the distribution of settlement proceeds in a manner that violates the statutory priority scheme.' Pet. for Cert. i," and the Court should dismiss due to this change.). 
transfer claims, their settlement, and the employees' mass layoff notice claims (WARN Act claims) - and the narrow holding. Part IV explores the powerful undercurrents of this case; first, the dicta guiding discretion in first-day orders and interim settlement approvals, and second, the implications about fee attitudes. Part IV also introduces a discussion of the dynamics of settlements inside the reorganization process, which divides in two: the propriety of priority-violating settlements, and the difference between the class that should litigate versus the class that should settle a dispute. The conclusion stresses the narrow nature of the holding and the expansive implications of these undercurrents.

\section{Exits: Statutory and Not}

The statutorily foreseen ways to exit a reorganization are plans, conversions to liquidation, and dismissals. These exit strategies are discussed in Subpart A. Judicial discretion ${ }^{4}$ and practice have created two more ways to exit a reorganization. Subpart B discusses sub rosa plans through $\& 363$ sales, and Subpart C discusses structured dismissals.

\section{A. Plans, Conversions, and Dismissals}

The Bankruptcy Code provides for three specific ends to a reorganization process. Section 1129 offers an exit with either a consensual plan-subsection (a) or a nonconsensual one-subsection (b). If the reorganization does not end with a plan, then the Code establishes that the case may be converted to a liquidation under chapter $7, \S 1112$, or may be dismissed under $\$ 349$, which primarily envisions an undoing of the consequences of the bankruptcy. Plans of reorganization can be liquidating in that they distribute the proceeds of sales-mostly $\S 363$ sales. True restructurings often enable a business to overcome the freeze of insolvency and continue as a viable going concern. The non-liquidating reorganization plan constitutes the ultimate successful exit from a reorganization process, as it means the business is worth retaining as a going concern. ${ }^{5}$ The plan reschedules the claims against the business - obligations to creditors and shareholders' equity claims -in a way that ensures that a viable business emerges. ${ }^{6}$ If all classes of claimants agree with the appropriate majorities, then the reorgani-

4. Judicial discretion is a central feature of bankruptcy law, with the Bankruptcy Code ("Code") giving an open-ended authorization for it in 11 U.S.C. \& 105(a) (2012) "The court may issue any order, process, or judgment that is necessary or appropriate to carry out the provisions of this title."), and repeatedly and expressly allowing coutts to deviate from its mandates, pertinently in the section on dismissals, which begins with "unless the court, for cause, orders otherwise," id. \& 349.

5. The Code ensures that only businesses worth more as going concerns get reorganized by giving dissenting minority creditors a right to receive as much as or more than in liquidation, id. $\$ 1129($ a)(7)(A)(ii) (each holder of a claim who has not accepted the plan "will receive . . under the plan . . value . . not less than the amount that such holder would so receive... if the debtor were liquidated under chapter $7^{\prime \prime}$ ).

6. The Code requires that the reorganized entity is not likely to seek protection from its creditors again in the foreseeable future, id. $\$ 1129(\mathrm{a})(11)$ "Confirmation of the plan is not likely to be followed by the liquidation, or the need for further financial reorganization, of the debtor ...."). 
zation is consensual under $\$ 1129($ a), with dissenting minorities principally being entitled to liquidation value. ${ }^{7}$ If one or more classes of claimants objects, provided that at least one impaired class consents, ${ }^{8}$ then the court may confirm a nonconsensual plan under \& 1129(b). In nonconsensual plans, dissenting classes are entitled to additional protections, the relevant one here being their priority. Priority, also known as the absolute priority rule, means that each class is either paid in full or that no class junior to that class receives any value..$^{9}$

Conversions to chapter 7 liquidations are the Code's envisioned fate for businesses that prove that they should not be maintained as going concerns. ${ }^{10}$ Many sales are conducted during an attempted reorganization, and liquidating reorganization plans are common, obviating this conversion. The final alternative is dismissal. The Code's vision of dismissal is primarily a return to the situation that would have existed if the bankruptcy filing never took place. ${ }^{11}$

\section{B. Sub Rosa Plans Through $§ 363$ Sales}

Whereas the usual sale that the Code envisions is for cash, large transactions will often have more texture. ${ }^{12}$ Buyers may wish to retain staff and key suppliers and dealers or pay without cash (i.e., by means of debt, equity, or other rights). When the buyer retains staff or other relations and gives rights rather than cash, the transaction is no longer a simple conversion of the debtor's assets for an amount of cash that can be distributed according to priorities. The debtor's counterparties who receive employment by the buyer or other rights against the buyer (such claimants are seen as "following the assets" as opposed to staying behind in the reorganization to receive the proceeds of the sale) may end up being treated differently than they would be otherwise, and the rights that the

7. See supra note 5 .

8. The requirement that one impaired class supports the plan comes from the language of $\S 1129(\mathrm{~b})$ requiring that all subparagraphs of subsection (a) other than (a)(8) are met, which requires that (a)(10) be met, requiring that "at least one class of claims that is impaired under the plan has accepted the plan, determined without including any acceptance of the plan by any insider."

9. Section 1129 (b) requires the plan to be fair and equitable, which it defines to mean observation of priorities, meaning, for example, for unsecured creditors, that if they do not receive "value. equal to the amount of [their] claim" per (b)(2)(B)(i), then "the holder of any claim or interest that is junior to the claims of such class will not receive or retain under the plan on account of such junior claim or interest any property" per (ii). Id. \& 1129(b).

10. Id. $\$ 1112$ (establishing the power of the debtor and of the court to convert a chapter 11 case to chapter 7 or dismiss).

11. Id. $\$ 349$ ("(b) Unless the court, for cause, orders othenvise, a dismissal of a case other than under section 742 of this title-(1) reinstates-(A) any proceeding or custodianship superseded under section 543 of this title; (B) any transfer avoided under section $522,544,545,547,548,549$, or 724(a) of this title, or preserved under section $510(\mathrm{c})(2), 522(\mathrm{i})(2)$, or 551 of this title; and (C) any lien voided under section 506 (d) of this title; (2) vacates any order, judgment, or transfer ordered, under section $522(\mathrm{i})(1), 542,550$, or 553 of this title; and (3) revests the property of the estate in the entity in which such property was vested immediately before the commencement of the case under this title." (emphasis added)).

12. The sales discussed here are those outside the debtor's ordinary course of business. Sales in the ordinary course of business do not need court approval, id. \& 363(c)(1). Sales that liquidate a large part of the debtor or change the debtor's business line will almost necessarily be outside the ordinary course of business and, therefore, need court approval, id. $\$ 363(\mathrm{~b})$. 
buyer gives may have different value for different creditors. An extreme example is the travel vouchers that were proposed in Braniff, which were much more valuable to individuals than to corporate claimants (and which were not allowed). ${ }^{13}$

Despite these quirks, sales are eminently desirable. The law would be foolhardy to insist on cash-only transactions in the face of a deteriorating debtor, negotiation impasses, and the myriad of difficulties of a reorganization. Sales realize value, preserve going-concern value, resolve uncertainties, and restore productivity in ways that fundamentally promote the goals of the reorganization for the parties and the economy at large. Yet, these transactions likely produce deviations from the distributions that a cash-only sale would enable-deviations that partly depend on the future performance of the buyer-and they are, therefore, unknown at the time of the transaction. Depending on the subsequent success of the business under the buyer, counterparties that follow the assets may receive superior or inferior treatment. ${ }^{14}$ Claimants receiving rights will realize different values depending on status (e.g., those receiving equity doing better in success and those receiving secured debt experiencing better protection in failure). Sales that have distributional consequences are called sub rosa reorganization plans_sub rosa meaning "covert"-because the sale distributes the value of the debtor outside the process of plan approval per \& 1129. ${ }^{15}$

The conflict between the attraction of sales and their distributional consequences creates a conundrum; insisting on cash-only sales could be destructive. The cash-only sales necessary for exact compliance with \& 1129 may be impossible due to time and structural reasons. Courts have overcome this conflict by importing protections of $\$ 1129$ to sales that have distributional consequences. ${ }^{16}$ Scholarship ${ }^{17}$ and the ABI Chapter 11 Reform Report ${ }^{18}$ agree.

13. Pension Benefit Guar. Corp. v. Braniff Airways, Inc. (In re Braniff Airways, Inc.), 700 F.2d 935 (5th Cir. 1983).

14. The ultimate, almost, example of a $\$ 363$ sale followed by success is that of Chrysler. The dealers and retiree claimants, who would have fared extremely poorly in a liquidation, were essentially paid in full. See generally Mark J. Roe \& David Skeel, Assessing the Chrysler Bankruptcy, $108 \mathrm{MicH}$. L. REV. 727 (2010).

15. Technically, a formal reorganization plan will follow $\$ 363$ sales, usually a liquidating one, distributing the proceeds of the sale to the claimants that were left behind. Objecting and even defeating that plan, however, would not invalidate the prior $\$ 363$ sale, making the sale the salient point during which claimants' rights need to be assessed.

16. See, e.g., Institutional Creditors of Cont'l Air Lines, Inc. v. Cont'l Air Lines, Inc. (In re Cont'l Air Lines, Inc.), $780 \mathrm{~F} .2 \mathrm{~d} 1223,1228$ (5th Cir. 1986) ("If the court concludes that there has in actuality been such a denial [of a right that the objecting creditor would have under \& 1129], it may then consider fashioning appropriate protective measures modeled on those which would attend a reorganization plan."); In re Crowthers McCall Pattern, Inc., 114 B.R. 877, 885 (Bankr. S.D.N.Y. 1990) ("[W] a [settlement] transaction would free assets for distribution, and circumvent no Chapter 11 right, it may be approved as a necessary step toward, or building block of, a plan of reorganization."); see generally Craig Sloane, The Sub Rosa Plan of Reorganization: Side-Stepping Creditor Protections in Chapter 11, 16 BANKR. Dev. J. 37 (1999).

17. See, e.g., Roe \& Skeel, supra note 14, at 735-36 ("If a class consented overall but a dissenter would clearly be getting liquidation value, then the court could determine that even though the sale had aspects of a sub rosa plan, those features if done above-board would still have permitted plan confirmation under $\& 1129 . ")$.

18. Am. Bankr. Inst. Comm'n to Study the Reform of Chapter 11, 2012-2014 Final Report and Recommendations 206 (2014) [hereinafter ABI Chapter 11 ReForm Report] ("the Commission ultimately 
Sales are important for understanding Jevic; by virtue of involving a settlement, it involved a sale, and from an analytical perspective, settlements are sales. In a settlement, the estate's asset is a claim that gets replaced by a different asset through the settlement. If the settlement were for cash, no distributional issues would arise, because the cash could be distributed in the bankruptcy process with exactitude. Yet, settlements can have additional complexities.

The key opinion on the application of \& 363 in settlements that have distributive consequences is the Second Circuit's Iridium, which is repeatedly cited in Jevic. ${ }^{19}$ Motorola created a subsidiary, Iridium Operating LLC ("Iridium"), later spun off, to pursue global, satellite-based, mobile telephony. Iridium missed its target number of subscribers by almost 99 percent, leading to bankruptcy. ${ }^{20}$ All of its assets were encumbered in favor of lenders led by JP Morgan Chase Bank ("Chase"). Motorola held large claims and administrative claims. Unsecured creditors sought to challenge Chase's priority and impose liability on Motorola for its treatment of Iridium. ${ }^{21}$ The creditors reached a settlement with Chase that in part allocated funds to an entity that would pursue the litigation against Motorola, thus (a) allocating the proceeds of the settlement to the exclusion of Motorola, and (b) by allocating the ownership of the litigation entity, apportioning the potential proceeds of the litigation against Motorola. ${ }^{22}$ The Second Circuit adopted a balancing test, allowing small deviations from the scheme of \& 1129 for "good business" reasons:

Here, the bankruptcy court identified a proper business justification for the Settlement. By allowing [Chase] to take $\$ 92.5$ million and redirect another $\$ 37.5$ million to the [litigation entity] in exchange for the Committee dropping the challenge to the liens, the Committee has cleared the way for implementation of a reorganization plan. The Estate stands to gain significantly more from the action against Motorola than it might if it or the Committee were forced to fund the litigation themselves at some much later date.... In short, the bankruptcy court did not err in concluding that the settlement of the dispute of the liens ... had a proper business justification and was "a step towards possible confirmation of a plan of reorganization and not an evasion of the plan confirmation process." 23

determined that creditors should be afforded at least the same level of protection in the section $363 \mathrm{x}$ sale process and in the chapter 11 plan process").

19. In re Iridium Operating LLC, 478 F. $3 \mathrm{~d} 452$ (2d Cir. 2007) [hereinafter Iridium]. The Supreme Court's opinion mentions Iridium five times in the majority and once in the dissent. The Third Circuit opinion mentions Iridium fifteen times.

20. Id. at 456-57 (noting Iridium had a little over 10,000 subscribers when a million were projected for its viability-missing the target by about 99 percent).

21. Id. at 458 ("The Committee argued that Iridium had causes of action against Motorola for breach of contract, breach of fiduciary duty, and avoidance of fraudulent conveyances. . . According to the Committee, while Iridium was still a subsidiary 'Motorola caused Iridium to execute a series of one-sided, overreaching contracts extremely lucrative to Motorola and grossly unfair to Iridium from a financial, legal and risk allocation perspective.' The Committee further alleges that even after the spinoff, Motorola continued to dominate Iridium through a parasitic relationship that insulated Motorola from any risk associated with Iridium.").

22. See infra note 82 and accompanying text.

23. Iridium, 478 F.3d at 467. 
This sheds a particular light on the Iridium setting. The debtor has claims against two creditors, Chase and Motorola. The settlement with one funds the pursuit of the other. The court finds that this scheme promotes the purposes of disentangling the affairs of the debtor while offering the opportunity to increase the size of the estate, despite that the second creditor, Motorola, is excluded from the settlement's proceeds in a deviation from proper priorities. ${ }^{24}$

\section{Structured Dismissals}

Dismissals that do not erase the consequences of the bankruptcy filing are known as structured dismissals because the dismissal order contains language preventing the restoration of the status quo ante. Although the Code did not foresee structured dismissals, they have become virtually unavoidable. Moreover, the Code itself gave the bankruptcy court the authority to deviate for cause from dismissals that simply restore the status quo ante. ${ }^{25}$

To maintain the going concern, preserve value, or pursue opportunities for increasing the estate, the estate may benefit by giving rights or making payments to claimants or third parties. For example, the estate could waive security interests of the debtor against a creditor that becomes a post-petition lender, known as a debtor-in-possession lender ("DIP lender"). ${ }^{26}$ If dismissals removed all consequences of bankruptcy, then dismissals would undermine those efforts of the debtor. Instead, if the court authorized such transactions, and the subsequent dismissal preserved the consequences of those transactions, then the dismissal becomes a structured dismissal instead of a simply restorative dismissal.

If DIP lenders could not rely on any rights or liens they obtained during the bankruptcy, then DIP lenders would be less willing to lend and would charge higher interest rates. Making financing reorganizations rarer and more expensive directly impedes the function of bankruptcy law as a revitalizer of productivity frozen by insolvency. ${ }^{27}$ During the Jevic oral argument, even the opponents of that structured dismissal acknowledged the desirability of structured dismissals that uphold appropriate reliance interests. ${ }^{28}$ All sides agreed that hampering DIP

24. However, the claims against Motorola eventually failed. See infra notes $84-85$ and accompanying text.

25. See supra note 11 .

26. This example was used in oral argument. See infra note 29

27. See generally John Armour \& Douglas Cumming, Bankruptcy Law and Entrepreneurship, $10 \mathrm{Am}$. L. \& ECON. REV. 303 (2008) (empirical showing of correlation of lenient bankruptcy law with entrepreneurial activity); Nicholas L. Georgakopoulos, Bankruptcy Law for Productivity, 37 WAKE FOREST L. REV. 51 (2002)

28. Transcript of Oral Argument at 13, Czyzewski v. Jevic Holding Corp., No. 15-649, 137 S. Ct. 973 (2017) [hereinafter Jevic Transcript] (Ms. Spinelli for petitioners: 'the 'for cause' provision in Section 349(b) was intended to protect parties who took actions in reliance on the bankruptcy"); id. at 14-15 ("Section 349 says that-that the default when a bankruptcy case is dismissed is that certain transactions that occurred during the case, such as avoidance actions, get unwound, liens that have been voided are reinstated, and property remaining in the estate is returned to its prebankruptcy owner. In other words, the bankruptcy is undone as far as possible. The cause exception is an exception to that. So what the cause exception permits a bankruptcy court to do is to maintain the status quo at the time of dismissal when there is good reason to do so. And the typical good reason would be 
lending by avoiding rights granted to DIP lenders would be counterproductive. The same argument applies to any other counterparty that the estate needs to perform on a timely basis during the bankruptcy. While this appears to be most likely in financing the debtor's reorganization attempt, the debtor may need urgent care even if the debtor is going out of business but has sensitive assets (e.g., idling refineries, plants, or satellite systems).

Hand-in-hand with structured dismissals go the orders, issued by the court at the beginning of the case, that allow those transactions. Their desirability was conceded at oral argument. ${ }^{29}$ Those first-day orders were expressly approved by dicta in the Jevic opinion, provided that they promote appropriate bankruptcy interests. ${ }^{30}$ The ABI Chapter 11 Reform Report agrees. ${ }^{31}$ The corresponding theoretical analysis is even more permissive, building on the idea that the underlying relations are akin to an executory contract that the debtor may assume (and, thus, cure any defaults) with even less scrutiny. ${ }^{32}$

\section{JeVIC: Facts and OpINION}

Having understood the role of statutory and nonstatutory exits from the reorganization process, we now turn to the complicated facts of Jevic. In chronological order, the facts are a leveraged buyout, the failure of the business, the firing of the employees, the bankruptcy filing, the settlement of fraudulent transfer claims against the parent and the LBO lender in the structured dismissal, and the adjudication of the employees' claims for inadequate notice of their mass layoff under the WARN Act. Subpart A discusses the leveraged buyout, the fraudulent transfer claims, and their settlement. Subpart B is about the employees' wage and inadequate notice (WARN Act) claims. Subpart C explains the U.S. Supreme Court's narrow holding prohibiting nonconsensual structured dismissals.

\section{A. The lBO Fraudulent Transfer Claims}

Jevic Holding Corporation ("Jevic") was a subsidiary of a larger transportation company until 2006, when, on June 30, Sun Capital Partners IV, LP ("Sun"), a private equity fund, acquired it for $\$ 77.4$ million, taking a $\$ 90$ million bridge loan from Bank of Montreal (to cover not only the entire purchase price but also associated fees), refinanced within a month from CIT Group/Business

reliance by a party on something that happened during the bankruptcy case."); id. at 21 (Ms. Harrington for the United States: "[Payments violating priorities based on interim orders] are generally premised on a-on a prediction that-that allowing that kind of distribution will ultimately result in every creditor getting more money at the end of the day.").

29. Id at 13-14 (Ms. Spinelli, for the employees, discussing In re Wiese where dismissal did not allow the reinstatement of lien that the debtor had released in order to get financing).

30. See infra note 66 and accompanying text.

31. ABI CHAPTER 11 ReForm REPORT, supra note 18, at $87-91$ (discussing the "payment of certain claims upon filing").

32. 11 U.S.C. \$ 365(a) (2012) ("TT]he trustee, subject to the court's approval, may assume or reject any executory contract . . . of the debtor."). 
Credit, Inc. ("CIT"). 33 The refinancing produced two loans totaling a little over $\$ 101$ million, an $\$ 85$ million revolving line of credit ("revolver"), and a $\$ 16.2$ million term loan. Sun was not an obligor or guarantor under these loans, making them, colloquially, nonrecourse. The loans were secured with first liens on all of Jevic's assets, and the term loan was separately secured by real estate. Jevic was immediately in violation of loan covenants and, to obtain CIT's forbearance, sold and leased back the real estate. The proceeds repaid the term loan in full and reduced the revolver's balance to $\$ 55$ million. Jevic's financial condition deteriorated further, requiring further forbearance by CIT, until February 2008 , when Jevic hired an investment bank to find a buyer. In early April, Jevic attempted a restructuring that would have been completed in June. Rapidly deteriorating circumstances amid the onset of the Great Recession and the absence of viable buyers forced its board to authorize a bankruptcy filing on May 16, 2008. Jevic gave a termination notice to its employees on May 19, announced that it was ceasing operations, filed for bankruptcy on May 20, and later conducted a $\$ 363$ sale of its assets.

To summarize, Sun bought Jevic with no cash but with a large nonrecourse loan from CIT secured by Jevic's assets (i.e., in an extremely leveraged buyout). Then, Jevic proved unable to sustain its debt as the Great Recession unfolded. Jevic fired its employees, shut down, and entered a liquidating chapter 11 . The LBO claims are explained in four steps. The first step explains the principles of the application of fraudulent transfer law in LBOs. The second step reveals the transfer. The third step explains the subordination remedy. The fourth step discusses the settlement in Jevic.

\section{LBO Fraudulent Transfer Principles}

Leveraged buyouts that fail may give rise to fraudulent transfer claims in favor of creditors. The usual structure of leveraged buyouts has an LBO lender enable an acquirer to buy a target with the LBO lender getting claims against only the target - not the acquirer-secured by the assets of the target. In practice, various considerations produce variations, but the typical transaction has the acquirer form a corporation that initially has no assets, i.e., is a shell corporation. The acquirer endows the shell with some cash, the acquirer's equity (although in Jevic's case the acquirer contributed no cash). The shell also borrows the bulk of the purchase price from the LBO lender and grants to the LBO lender a security interest in all assets of the shell. Although at this moment the shell has no assets other than cash, this soon changes; the shell spends its cash (i.e., the acquirer's equity and the loan) to acquire the target's shares from its shareholders and merges with the target, two steps that become a single merger transaction. Upon the merger, as the two corporations become one, the obligation to the

33. The facts in this paragraph come from an amalgamation of the facts of two bankruptcy court opinions, one on the fraudulent transfer claims and one on the workers' WARN Act claims, In re Jevic Holdings Corp., No. 08-11006 (BLS), 2011 WL 4345204, at * 1 (Bankr. D. Del. Sept. 15, 2011); In re Jevic Holdings Corp., 496 B.R. 151, 154-56 (Bankr. D. Del. 2013). 
LBO lender and the lien in favor of the LBO lender become an obligation of the merged entity, and upon the proper filings to perfect the security interest, a lien attaches to all assets of the merged entity. The assets of the merged entity are only the assets of the target, the cash of the shell having gone to the old shareholders of the target. Through this transaction, the claim of the LBO lender takes priority over unsecured claims against the target. LBO practice may further aggravate the target's finances, for example, by the acquirer charging fees to the target for managing it, as is the practice of some private equity acquirers, or by the target distributing dividends to the acquirer. ${ }^{34}$

If the merged entity fails, as Jevic did, then the preexisting creditors of the target are, quite naturally, harmed by the leveraged buyout. If the leveraged buyout had not occurred, the target would have less debt and may not have failed, and its creditors' claims would be first in line for payment instead of queueing behind the LBO lender. Fraudulent transfer law may give them a remedy. Naturally, the creditors of Jevic sought to use fraudulent transfer law against CIT's offending priority and to recover any funds that Sun may have obtained from Jevic.

Fraudulent transfer law prohibits transactions of two kinds, those intended to "hinder, delay, or defraud" creditors ${ }^{35}$ (called intentional fraud in the traditional language of fraudulent transfer law) and transactions that leave the debtor in three specific poor financial positions without the debtor obtaining reasonably

\footnotetext{
34. Justice Breyer's opinion explains this:

In a leveraged buyout, the buyer (B [or acquirer]) typically borrows from a third party ( $\mathrm{T}$ [or $\mathrm{LBO}$ lender]) a large share of the funds needed to purchase a company ( $\mathrm{C}$ [or target]). $\mathrm{B}$ then pays the money to C's shareholders. Having bought the stock, B owns C. B then pledges $C$ 's assets to $T$ so that $T$ will have security for its loan. Thus, if the selling price for $C$ is $\$ 50$ million, B might use $\$ 10$ million of its own money, borrow $\$ 40$ million from $\mathrm{T}$, pay $\$ 50$ million to Cs shareholders, and then pledge $C$ assets worth $\$ 40$ million (or more) to $T$ as security for $T$ 's $\$ 40$ million loan. If $B$ manages $C$ well, it might make enough money to pay $\mathrm{T}$ back the $\$ 40$ million and earn a handsome profit on its own $\$ 10$ million investment. But, if the deal sours and $C$ descends into bankruptcy, beware of what might happen: Instead of Cs $\$ 40$ million in assets being distributed to its existing creditors, the money will go to $\mathrm{T}$ to pay back T's loan-the loan that allowed B to buy $C$. ( $T$ will receive what remains of C's assets because $T$ is now a secured creditor, putting it at the top of the priority list.).
}

Czyzewski v. Jevic Holding Corp., 137 S. Ct. 973, 980 (2017).

Justice Breyer's explanation uses the terms buyer (B), third party lender (T), and company (C) whereas the explanation in the text uses the terms acquirer, LBO lender, and target, but the substance is the same. In the setting of Jevic, Sun (the acquirer or B) created a shell to borrow from CIT (the LBO lender or T) and buy Jevic (the target or C). The creditors of the old Jevic found themselves queueing for distributions from the failed merged entity, behind CIT's secured claim.

35. The state law source of fraudulent transfer law is usually one of the corresponding uniform acts, ranging from the most recent Uniform Voidable Transactions Act ("UVTA"), its marginally different predecessor-the Uniform Fraudulent Transfers Act-which was intended to be synergistic with the Bankruptcy Code, or the significantly older Uniform Fraudulent Conveyances Act; bankruptcy has parallel provisions in \$ 548. Intentional fraud: 15. U.S.C. \& 548(a)(1) (2012) ("The trustee may avoid any transfer . . . if the debtor ... (A) made such transfer . . with actual intent to hinder, delay, or defraud any entity to which the debtor was . . indebted."); UVTA \& 4(a)(1) (2016) ("A transfer made . . . is voidable . . if the debtor made [it] (1) with actual intent to hinder, delay, or defraud any creditor...."). 
equivalent value (constructive fraud). The three poor positions are insolvency, inability to service one's debts, and unreasonably small assets. ${ }^{36}$

The ordinary remedy that fraudulent transfer law provides is avoidance of the offending transfer. ${ }^{37}$ In the case of leveraged buyouts, however, identifying the offending transfer is difficult, and avoidance of the transfer to the selling shareholders is excessive if the selling shareholders had no bad faith. Both the Bankruptcy Code and fraudulent transfer law also let the court devise any other appropriate remedy. ${ }^{38}$ The remedy that the courts often devise is the subordination of the claims of the LBO lender and any claims of the acquirer.

\section{Unearthing the Transfer}

The application of fraudulent transfer law in leveraged buyouts faces the difficulty that the offending transfer is obscured by the flexibility of mergers in modern corporate practice. To see the transfer, some digging is necessary. One must separate in time the acquisition of the target's shares from the merger so as to suppose that the target continues to exist after the acquisition as a wholly owned subsidiary of the shell. The setting is that the acquirer created the shell and endowed it with some equity, and that the shell borrowed from the LBO lender and spent all its cash acquiring all of the target's shares. But the merger has not yet occurred. Therefore, the LBO lender is only a lender to the shell, and its security interest only covers the shell's assets, i.e., the shares of the target, rather than the assets of the target. In this setting, for cash to reach the LBO lender, the shell must have the target declare dividends to the shell, which can then pay its obligations to the LBO lender.

Consider the position of the creditors of the target at this moment. They are sufficiently protected by fraudulent transfer law because the target cannot declare dividends that would render it insolvent or unable to service its debts. Dividends are transfers for less than reasonably equivalent value-for no value. The payment of such a dividend would be constructive fraud and avoidable.

Consider next, that instead of the merger, an equivalent outcome arises from a longer sequence of simpler transactions. The shell has already borrowed from the LBO lender and acquired the shares of the target. Now, the target borrows

\footnotetext{
36. 15 U.S.C. $\$ 548(a)(1)$ (B) ("The trustee may avoid any transfer . . if the debtor . . (B)(i) received less than reasonably equivalent value ... and (ii)(I) was insolvent . . . ; (II) [had] unreasonably small capital [for the line of business]; [or] (III) [had] debts that would be beyond the debtor's ability to pay as such debts matured."); UVTA $\S \S 4(a)(2), 5(a)$ (2016) ( 8 4(a): "A transfer . . is voidable ... , if the debtor made [it]: . . (2) without receiving a reasonably equivalent value . . , and the debtor: (i) was . . . in a business . . for which the remaining assets of the debtor were unreasonably small ...; or (ii) ... reasonably should have believed that the [debtor's] debts [would be] beyond the debtor's ability to pay as they became due."; \& 5(a): "A transfer made . . is voidable . . if the debtor made the transfer ... without receiving a reasonably equivalent value . . and the debtor . . . became insolvent as a result ....").

37. 11 U.S.C. \& 548(a)(1) ("The trustee may avoid any transfer ...."); UVTA \& 7(a)(1) (2016) ((a) "a creditor . . may obtain: (1) avoidance of the transfer").

38. UVTA \& 7(a)(3)(iii) (2016) (a creditor may obtain "any other relief the circumstances may require"); 11 U.S.C. \& 105(a) (2012) ("The court may issue any order, process, or judgment that is necessary or appropriate to carry out the provisions of this title.").
} 
from the LBO lender an amount equal to the shell's indebtedness to the LBO lender. The target then sends that amount as a dividend to the shell; the shell then repays its loan to the $\mathrm{LBO}$ lender and dissolves, distributing its assetsthe shares of the target-to its shareholders. The new loan comes from the LBO lender and is secured by the target's assets. Therefore, the end result is identical to the single-step transaction: the acquirer owns the target, and the target's assets secure the obligation to the LBO lender. ${ }^{39}$ However, in this sequence, the transfer that may be fraudulent is visible. The application of fraudulent transfer law focuses on the dividend. If the target does not become insolvent or unable to service its debts by distributing this dividend, then this transaction does not violate fraudulent transfer law. Worth noting is that, as long as the LBO lender is pursuing its own self-interest as a long-term lender to the target as a going concern, then the LBO lender would ensure that the target continues to be viable and able to service its debts, which include the obligation to the LBO lender.

\section{The Subordination Remedy}

Because the outcome of the leveraged buyout is possible without the singletransaction shortcut of the merger, fraudulent transfer law also has no reason to stand in the way of producing this result with a single step-through a merger of the shell with the target while the target's shares are still owned by its old shareholders (in which merger, target's shareholders only receive cash-the equity and loan proceeds of the shell). The separation of the merger into its constituent steps, however, reveals the potentially offending transfer: the large dividend from the target to the shell that enables the LBO lender to become a creditor of the target. One may justifiably think that when this dividend is visible, then the court that applies fraudulent transfer law would more easily enjoin it or void it as a fraudulent transfer. However, courts have effectively protected creditors in single-step LBO transactions, mostly by subordinating LBO lenders' claims. ${ }^{40}$ Seen from the perspective of the disaggregated transaction, if the hypothetical dividend would have violated fraudulent transfer law, then the LBO lender should not be allowed to become a secured creditor of the target. Subordination of the LBO lender's claim makes the claims of other creditors of the target have priority over the LBO lender.

That leveraged buyouts, despite good faith, may give rise to subordination of LBO lenders' claims per fraudulent transfer law is best exemplified in O'Day. ${ }^{41}$ In this opinion of extraordinary length and detail, the court found that the LBO lender, Meritor, that enabled the acquirer, Funston, to buy the target (the sailboat manufacturer O'Day), was too aggressive and too optimistic. ${ }^{42}$ Rather

39. See Nicholas L. Georgakopoulos, Fraudulent Transfers IIl-Leveraged Buyouts, www.cali.org/ lesson/16127 [archived at https://perma.cc/4CL8-EK6U] (last accessed June 29, 2017) (CALI lesson including animated visuals of the sequence of transactions).

40. See, e.g., Murphy v. Meritor Savings Bank (In re O'Day), 126 B.R. 370 (Bankr. D. Mass. 1991).

41. See id.

42. Id. at 407 ("The Court finds, therefore, that the earnings assumptions upon which Jones lof Meritor, the LBO lender] and Funston based their projections were unreasonable and, as a result, 
than the acquirer shopping for an LBO lender, the LBO lender found the acquirer. ${ }^{43}$ Rather than a low-fee long-term loan, the LBO lender extracted large fees upfront ${ }^{44}$ as well as a range of interest rates, reaching a premium of at least 4.5 percent over treasury rates. ${ }^{45}$ Rather than making conservative estimates of the target's future profits, the LBO lender trivialized the risks to enable the transaction. ${ }^{46}$ The remedy was that the LBO lender lost its security interest and was subordinated to other creditors of the target. ${ }^{47}$

The details of the buyout of Jevic are not described with the extraordinary detail of O'Day. Therefore, the fate of a fraudulent transfer claim is unclear. The fact that the loan was significantly greater immediately after the transaction than the price paid for Jevic suggests that the LBO loan rendered Jevic insolvent. In addition, the business appeared unable to turn a profit at any time after the LBO, suggesting that Jevic may also not have been able to pay its debts as they became due. However, Jevic's inability to service its debts may have been an unforeseeable result of the onset of the Great Recession, whereas the reasonable forecast at the time of the transaction may have been that Jevic would be able to service its debts, in which case fraudulent transfer liability would be unlikely. ${ }^{48}$

\section{The Settlement}

The creditors of Jevic, by arguing that the leveraged buyout of Jevic violated fraudulent transfer law, pursued the same remedy. The allegation of a fraudulent transfer in the LBO of Jevic could have led to subordination of the claims of the LBO lender, CIT, and the voiding of any transfers from the target, Jevic, to the

the projections themselves were unreasonable."); id. at 412 ("The Court finds that the Bank and Funston suffered from an overweening optimism about the Debtor's financial abilities, and their own, which addled their ability to evaluate the company in light of its financial condition in the months prior to the LBO, and permitted them to disregard the cyclical nature of the Debtor's business and the industry.").

43. Id at 375 ("In early 1987, Meritor became aware of Forstmann's desire to sell O'Day .... Due to its relationship with [Funston], Meritor also was aware that Funston was engaged in the business of acquiring corporations. Indeed, [Jones], a senior lending officer at Meritor, who testified he had been involved in approximately 10-15 LBO deals in 1986, contacted Funston to inform him about the sale of O'Day." (footnote omitted))

44. Id. at 382 ("In an undated letter, [Freal], a Bank officer who worked with Jones, advised Funston that the amount of fees due Meritor at closing would be $\$ 119,263.88 . ")$.

45. The one-year treasury rates on June 1987 were about 6.8 percent and the five-year at about 8.4 percent, FED. RE5. ECON. RE5., fred.stlouisfed.org (last visited June 29, 2017). O'Day's "deferred interest acquisition loan" at 13 percent corresponded to a premium over one-year treasuries of 6.2 percent and 4.6 percent over five-year treasuries. The "term loan" was set at 4.5 percent over treasuries, unclear which. The "revolving line of credit" was set at 2.75 percent over a "base rate" that is unclear. Id. at 381 ("Meritor provided the following credit facilities: 1. A term loan ...., plus interest payable monthly at $4.5 \%$ above a specified treasury securities yield rate . . ; 2 . A revolving line of credit . . , with interest payable monthly at $2.75 \%$ above Meritor's base rate . . ; 3 . A deferred interest acquisition loan ... ; plus interest payable monthly at $13 \%$. . .".).

46. See supra note 42 .

47. O'Day, 126 B.R. at 413 ("the Court rules that the liens and security interests obtained by Meritor on June 30, 1987 are void . . . [;] the Court equitably subordinates all of Meritor's claim").

48. Moody v. Sec. Pac. Bus. Credit, Inc., 971 F.2d 1056 (3d Cir. 1992) (refusing to impose LBO fraudulent transfer liability because the forecasts at the time of the LBO were reasonably for solvency and were upset by the advent of a recession). 
acquirer, Sun. Rather than litigate the issue, the parties reached a settlement. The settlement had Sun surrender a lien on the debtor's only asset, \$1.7 million of cash, and had CIT contribute $\$ 2$ million for a total settlement amount of $\$ 3.7$ million. ${ }^{49}$

Normally, the recipient of these funds would be the estate of the debtor. However, Sun argued that because the litigation over the employees' inadequate notice (WARN Act) claims was active and included Sun as a defendant, giving the proceeds of the settlement to the estate would in essence have been financing litigation against Sun. Therefore, Sun insisted that the settlement should not fund the employees' litigation against Sun and that the employees be excluded from the settlement proceeds. Thus, the structured dismissal order that approved the settlement and ordered its distribution to other creditors was violating the employees' wage priority claim, as the next subpart explains.

\section{B. The Wage and Inadequate Notice (WARn Act) Claims}

The employees who were fired on the eve of bankruptcy made two kinds of prepetition claims, ordinary claims for back wages and inadequate notice (WARN Act) claims. Employers of more than 100 employees, like Jevic, are subject to the federal WARN Act's mandate that in the event of a mass layoff, they give sixty days' notice to their employees. ${ }^{50}$ New Jersey, where Jevic was headquartered, has its own even stricter WARN statute. ${ }^{51}$ Recent prepetition claims for wages, which include those under the WARN Acts, receive (up to $\$ 10,000$ per employee), a priority that makes them senior to unsecured claims but junior to administrative and secured claims. ${ }^{52}$

Although the federal WARN Act contains exceptions that protect failing businesses, the New Jersey WARN Act does not. Accordingly, Jevic owed sixty days' wages to its employees as of the date of their dismissal on the eve of bankruptcy. ${ }^{53}$ The employees argued that accordingly, they have a claim for $\$ 12.4$ million, with

49. Czyzewski v. Jevic Holding Corp., 137 S. Ct. 973, 981 (2017).

50. 29 U.S.C. \& 2102 (2012) ("An employer shall not order a plant closing or mass layoff until the end of a 60 -day period after the employer serves written notice.").

51. N.J. STAT. ANN. \& 34:21-2 (West 2016) ("[T] he employer who operates the establishment or conducts the mass layoff shall: a. Provide, in the case of an employer who employs 100 or more full-time employees, not less than 60 days, . . . , before the first termination of employment occurs in connection with the termination or transfer of operations, or mass layoff, notification.").

52. Secured claims are senior-most by virtue of being entitled to the collateral, $\$ \$ 725,1129(\mathrm{~b})(2)(\mathrm{A})$. Then, administrative priority claims, including legal fees, receive the priority of $\$ 507(\mathrm{a})(2)$. Prepetition wage claims, including in this case the WARN Act claims, receive the fourth priority of wages per \& 507(a)(4) up to $\$ 10,000$ per employee and, perhaps, although not mentioned in the Jevic record, the fifth priority of employee benefit plan contributions per $\S 507(\mathrm{a})(5)$, again up to $\$ 10,000$ per employee. If the employee class dissents, then the plan must give this amount in cash, $\$ 1129(\mathrm{a})(\mathrm{9})(\mathrm{B})$ ("a class of claims of a kind specified in section . . 507(a)(4), 507(a)(5), . . of this title, . . will receive . . (ii) if such class has not accepted the plan, cash . . . equal to the allowed amount of such claim").

53. In re Jevic Holdings Corp., 496 B.R. 151, 165 (Bank. D. Del. 2013) ("[T]he Court finds that . . the Debtors are entitled to the Unforeseeable Business Circumstances exception[,]" but "that Class Plaintiffs are entitled to recovery under the New Jersey WARN Act."). 
$\$ 8.3$ million of that being entitled to the priority of wages. ${ }^{54}$ The employees also turned their WARN Act claims against Sun, but without success. ${ }^{55}$ However, the employees had also received a $\$ 6$ million payment of back wages on the basis of a first-day order. ${ }^{56}$ Not clear on the record is whether the employees' $\$ 8.3$ million priority claim accounted for the $\$ 6$ million they received on the basis of this firstday order, but probably not.

The exact size of the employees' priority claim is relevant because an important factor of the lower courts' analysis was the employees' harm from a rejection of the settlement and conversion to chapter 7 . The lower courts reasoned that the settlement of the LBO fraudulent transfer claims would not have taken place if the settlement had been rejected. ${ }^{57}$ Therefore, the employees would not have received anything more; as a result, the structured dismissal did not hurt them. An interesting question, however, is how much better the employees would have fared if the settlement amount was included. If so, the amount that the employees received in the first-day order would have counted toward their wage priority, probably leaving only $\$ 2.3$ million of their WARN Act claims with a wage priority. The total settlement proceeds of $\$ 3.7$ million would have fully covered the employees' wage priority and leave about $\$ 1.4$ million for other creditors. This does not account for administrative priority claims, which include the costs of operating the estate. Administrative claims would have had priority over the employees' claims. Thus, depending on the exact level of administrative claims, which should include the litigation about the settlement itself in the Third Circuit and the Supreme Court, the statement of Jevic's counsel at oral argument that the employees would receive nothing more either way may be correct, even if the settlement amount was included. ${ }^{58}$

54. Czyzewski v. Jevic Holding Corp., 137 S. Ct. 973, 980 (2017) ("The Bankruptcy Court granted summary judgment for petitioners against Jevic, leaving them (and this is the point to remember) with a judgment that petitioners say is worth $\$ 12.4$ million. . . Some $\$ 8.3$ million of that judgment counts as a priority wage claim under 11 U.S.C. $\$ 507(\mathrm{a})(4)$, and is therefore entitled to payment ahead of general unsecured claims against the Jevic estate.").

55. Id. at 981 ("Sun prevailed on the ground that Sun was not the workers' employer . ...").

56. Jevic Transcript, supra note 28 , at 39 (Mr. Landau for Jevic: The employees' "objection would actually completely come back to bite them because there is no legal difference between a distribution of assets on the first day where they recovered $\$ 6$ million in this case in their prepetition wage and benefit claims.").

57. Jevic, 137 S. Ct. at 982 ("[T]he court predicted that without the settlement and dismissal, there was 'no realistic prospect' of a meaningful distribution for anyone other than the secured creditors.").

58. Jevic Transcript, supra note 28 , at 30 ("Petitioners say that the bankruptcy court here was required to reject the settlement that made all other unsecured creditors better off without making Petitioners any worse off."). A fuller statement would explain that even if the employees won their fraudulent transfer attack on the LBO, their remedy would be subordination of CIT's claims against Jevic and recovery of payments to CIT and Sun, about the size of which the record is silent. The proponents of the plan would then point out that because the estate was administratively insolvent, that victory would not produce value for the employees. However, because CIT and Sun did provide $\$ 3.7$ million in the settlement, the question is to what probability of success of the fraudulent transfer claim does this settlement correspond, i.e., to what percentage of the recovery if the estate won the fraudulent transfer case. Because we do not know the total recoverable from CIT and Sun, we cannot answer. If one believes that the probability of success of a fraudulent transfer attack is high, then the settlement would only be appropriate if the $\$ 3.7$ million is a high fraction of the possible recovery. 
However, the Supreme Court pointed out that the structured dismissal approving the settlement prohibited the employees from pursuing their own fraudulent transfer claims against the acquirer, Sun, and the LBO lender, CIT. Therefore, even if the employees would get nothing out of Jevic from undoing the structured dismissal, they might get something from pursuing the LBO fraudulent transfer claims against Sun and CIT outside of bankruptcy, after a simple dismissal that would restore their right to that attack. ${ }^{59}$ The debtor would counter, however, that an invalidation of the dismissal brings the bankruptcy case back to life, and that the adjudication of the fraudulent transfer claims is a matter for the bankruptcy court, wherein the debtor, in light of the administrative insolvency, can only pursue those claims by obtaining counsel on a contingency-fee basis. During oral argument, the employees claimed that this was possible. ${ }^{60}$

\section{The Narrow Holding: "No" Structured Dismissais}

The actual holding of Jevic seems very simple. Dismissals need consent to violate priorities:

Can a bankruptcy court approve a structured dismissal that provides for distributions that do not follow ordinary priority rules without the affected creditors' consent? Our simple answer to this complicated question is "no." 61

The Jevic court says "no" to nonconsensual structured dismissals. The court does not deviate from the guidance of the ABI Chapter 11 Reform Report, which also disapproves of structured dismissals. ${ }^{62}$ This "no" of Jevic, however, is qualified.

First, consensual structured dismissals, about which the court was silent, remain proper. ${ }^{63}$ However, the court gave no guidance as to whether a class approval suffices or if the objecting minority in a class may still block a structured dismissal. In other words, what is unclear is whether the creditor's right to object to a structured dismissal is an individual right or a class right. A broad reading would argue for an individual right, in which case the number of structured dismissals that would be consensual is vanishingly small. A reading in the context

59. Jevic, 137 S. Ct. at 983 ("Ot the court could simply dismiss the Chapter 11 bankruptcy, thereby allowing petitioners to assert the fraudulent-conveyance claim themselves.").

60. Jevic Transcript, supra note 28 , at 5 (Ms. Spinelli: "The trustee would have to retain contingency counsel, and that does happen. I was involved in a Chapter 7 case where the trustee pursued an avoidance action successfully with contingency counsel.").

61. Jevic, 137 S. Ct. at 983.

62. ABI ChAPTER 11 ReFORM RePORT, supra note 18, at 293 (stating that the Commission agreed that only statutory exits be strictly approved, i.e., plans, conversions, and the court may "dismiss a case provided that the requested dismissal and the dismissal order satisfy the applicable provisions of, and do not permit the parties to work around, the Bankruptcy Code").

63. One may wonder about the possibility that the court may later expand this "no" to even consensual structured dismissals. This seems highly unlikely. An attempt to prohibit consensual structured dismissals would be practically almost pointless because virtually all such dismissals could also be presented as reorganization plans deserving approval by virtue of being consensual (the caveat regards some rights of priority claimants to accelerated payment, see infra note 70 ). Moreover, the court's dicta in favor of first-day orders imply that some nonconsensual structured dismissals must be proper, see infra text accompanying note 65 , which negates dogmatic opposition to structured dismissals. 
of $\$ 1129$ finds that Jevic recognizes only a class right to object to a structured dismissal. Minority dissenters in the reorganization setting, according to this reading, only receive rights analogous to those they have under $\S 1129$. Because $\S 1129$ only gives individual dissenters a right to their liquidation value, a structured dismissal that gives minority dissenters of a consenting class their liquidation value could be argued to be proper. The creation of an individual right by Jevic also seems counter to the structure of $\$ 1129$ and that of chapter 11 . When $\S 1129$ grants rights to claimants, those are usually class rights, and only by exception are they individual rights-a drafting principle that should carry over to Jevic. The structure of chapter 11 is inimical to individual holdouts, whereas an individual right to object to a structured dismissal would create a holdout problem, giving veto power in every individual creditor over a structured dismissal. This silence of Jevic allows different circuit courts to develop interpretations of Jevic on this aspect that may differ.

Second, the court discusses Iridium's priority-violating settlement with approval. ${ }^{64}$ The court's dicta approving and distinguishing Iridium are the second exception to Jevic's "no." The Jevic opinion does not disapprove of settlements that exclude claimants from their proceeds, provided that, like Iridium, they are in interim orders rather than final orders (and that the violation furthers a bankruptcy reason, such as Iridium's attempt to enlarge the estate as discussed below in Part IV.C). The following question then arises: what difference would the new rule have made to this particular settlement? The pertinent exercise asks whether the settlement could have been approved as an interim order, as in Iridium, pending the resolution of the WARN Act litigation against the acquirer, Sun. However, if the approval of the settlement was an interim order, then the next question is whether it could also make an interim distribution of the assets to the unsecured creditors, either excluding the employeeswhich seems highly unlikely, especially because the settlement cannot be seen as financing an attempt to increase the estate-or reserving assets for paying the employees after the resolution of the WARN Act litigation against Sun. The absence of an interim distribution would make the settlement much less appealing to the unsecured creditors, perhaps even pointless for them, but it would make it more appealing to employees. In addition, this would render Sun's insistence that the proceeds of the settlement not be shared with the employees pointless because the proceeds would not finance the litigation against Sun. The litigation would be over, and the proceeds could be distributed according to priorities. Thus, turning the agreement into an interim order would eliminate its disagreement with priorities, which shows that the Jevic opinion does have a substantive thrust: to uphold the Code's distribution scheme.

Third, the Jevic opinion offers a class of exceptions for first-day orders that would be appropriate:

64. Jevic, 137 S. Ct. at 985 ("We recognize that Iridium is not the only case in which a court has approved interim distributions that violate ordinary priority rules. But in such instances one can generally find significant Code-related objectives that the priority-violating distributions serve."). 
Courts, for example, have approved "first-day" wage orders that allow payment of employees' prepetition wages, "critical vendor" orders that allow payment of essential suppliers" prepetition invoices, and "roll-ups" that allow lenders who continue financing the debtor to be paid first on their prepetition claims. . . In doing so, these courts have ustally found that the distributions at issue would "enable a successful reorganization and make even the disfavored creditors better off." 65

A twist on the Jevic facts reveals the exception. Suppose that in the first-day order, which paid $\$ 6$ million to the workers, Jevic had negotiated and obtained a waiver by the workers of their WARN Act and fraudulent transfer claims (both types of claims were clearly foreseeable). Then, at an identical structured dismissal, the workers objected so as to pursue their waived claims. The workers' objections would obviously be improper in that they would contradict the waiver of their further claims. Because the Supreme Court's dicta indicate that such a first-day order would be proper, this nonconsensual structured dismissal should also be proper. In many circumstances, a proper first-day order would imply that its beneficiary cannot object to the structured dismissal that upholds the order's consequences.

\section{Through the Mirror: Undercurrents and Expansions}

Thus, the dicta about first-day orders take special importance, as does the hidden issue regarding potential biases about legal fees and settlements, their propriety, and the potential divergence between the class appropriate to litigate them versus settling, the four issues to which Part IV turns.

\section{A. First-Day Orders}

The guidance that the Court offers about first-day orders is limited to the dictum that they must benefit the estate and, thus, also dissenting creditors by "enabl[ing] a successful reorganization and mak[ing] even the disfavored creditors better off." 66 At oral argument, the Solicitor General pointed out that firstday orders that truly benefit the estate are supported by senior creditors and argued that first-day orders should be conditional on senior creditors' approval. ${ }^{67}$ However, the court did not approve of this expressly stringent standard. Rather, its dicta supported a first-day order practice that is guided by benefitting the estate and, thus, "even disfavored creditors" without expressly requiring the disfavored creditors' approval. An interesting puzzle regards the application of this standard to the first-day order paying the employees in Jevic itself. The business

65. Id. at 985 (citations omitted).

66. Id. (quoting In re Kmart Corp., 359 F.3d 866, 872 (7th Cir. 2004)).

67. Jevic Transcript, supra note 28 , at 21 (Ms. Harrington: "So in our view, [interim] distributions in Chapter 11 that violate the priority scheme are not permissible under any circumstances unless there is consent of the impaired priority claimholder. And so critical vendor orders, if they are done over the objection of the-of the claimholder who [was] skipped, we think those are not permissible...."). 
was already closing down. Thus, it was not easy to support a bankruptcy reason for the first-day order. Granted, Jevic needed some employees for the shutting down. ${ }^{68}$ However, Jevic did not present a true necessity for continued services in the broad and unqualified nature of the order (i.e., the payment to all employees).

Juxtaposing this first-day order-the unqualified payment of back wages to employees-with the corresponding recommendation of the ABI Chapter 11 Reform Report is revealing. The recommendation is to make routine the payment of back wages with no court approval. ${ }^{69}$ This reveals the likely reasoning behind the first-day order in Jevic. Although many employees were not likely necessary for Jevic's reorganization, the practice has developed to pay back wages on a first-day order due to their priority (and up to it). The way the facts unfolded, however, also shows the problems that this creates. Whereas the estate did not truly need the employees' service because the business closed, the absence of those funds made the estate administratively insolvent and unable to exit the reorganization process properly. Jevic changes this practice for settings where no bankruptcy reason exists to retain all employees (i.e., in most liquidating reorganizations). ${ }^{70}$

The payment of the employees on a first-day order in Jevic did not meet the standard that the court set. The employees were not necessary for a reorganization. Thus, no bankruptcy reason existed for this payment. Although the Jevic employees were victorious, the decision hurts similarly situated employees by scrutinizing their payments. The dicta strongly indicate that first-day orders to pay employees without a bankruptcy reason are not proper. Paying the employees with less haste may have created the space for a settlement that would have reduced litigation and sped resolution. A more deliberate negotiation with the employees might have led to a deal that addressed their (easily foreseeable) WARN Act claims and LBO fraudulent transfer claims. This kind of order

68. The employees that Jevic needed were mostly those necessary to complete pending deliveries and to return its trucks to their bases, see Dan Dooley, Jevic Holding Corp-The Supreme Court Issue and Ruling, and the Impact on Future Chapter 11 Cases (May 2017) (unpublished presentation, excerpt archived at https://perma.cc/4BGF-WV44) (discussing the completion of shipments and recovery of every single tractor and 98 percent of trailers; Mr. Dooley of Morris Anderson was the Chief Restructuring Officer of Jevic, overseeing its slide into bankruptcy and its liquidation).

69. ABI Chapter 11 Reform Report, supra note 18 , at 92 ("section 549 should be amended to permit the trustee to pay prepetition employee wages, other compensation, and benefit plan contributions up to the per employee priority limit without requiring the filing of a motion or order of the coutt").

70. A potential future conflict, however, is visible. Section 1129 requires the accelerated payment of some priority claims, 11 U.S.C. \& $1129(\mathrm{a})(9)$ (including "(B) with respect to a class of claims of a kind specified in section 507(a)(1), 507(a)(4) [priority wages], 507(a)(5) [priority benefits], 507(a)(6), or 507 (a) (7) of this title, each holder of a claim of such class will receive... (ii) if such class has not accepted the plan, cash on the effective date of the plan equal to the allowed amount of such claim"). The outstanding priority claims of employees, then, make liquidating reorganization plans that do not have sufficient assets violate $\& 1129$ (a)(9). The interpretation favorable to liquidating plans is that these rights are contingent on the existence of the value to make those payments, because conversion to chapter seven would not produce additional value. An insistence on a narrow reading of the text, however, would require conversions to chapter seven that would be, in essence, pointless and costly. 
would have avoided the many trips to the courthouse on the WARN Act claims and would have helped resolve the estate.

Thus, the most pronounced consequence of Jevic is that a new practice will develop about orders to pay employees in liquidating reorganizations, likely waiving further claims, accepting setoffs, or allowing marshalling of the payment against future priority claims. The Jevic problems would not have arisen if the employees had waived their rights to separately wage a fraudulent transfer attack against the LBO, and the setting would be much simpler if it had been clear that the payment the employees received would count against any additional priority claims that the employees would obtain.

The first undercurrent of Jevic requires this more cautious approach to first-day orders. The payment must be truly necessary; it must have a bankruptcy reason. Perhaps a closed business without assets that need active care can still pay back wages early, but more deliberation and negotiation should ensure that the payment also resolves pending issues, making "even disfavored creditors better off."71

\section{B. Biases About Fees}

The debate on the agency costs of bankruptcy professionals is intense. Professor Lynn LoPucki has created a long trail of scholarship arguing that the Code's ease of forum selection combined with the willingness of some courts to compete for bankruptcy filings has produced an environment in which legal fees are out of control, and the courts' actual discretion is in some ways limited. ${ }^{72}$ On the other side of this debate, Professor Stephen Lubben argues that competition among bankruptcy professionals is true and intense, mitigating concerns, and that the proffered evidence can be explained by fees being commensurate to the difficulty of the various categories of cases. ${ }^{73}$ Notice the parallel nature of this debate to the debate in corporate law scholarship about whether state competition produces a race to the bottom (i.e., is perniciously facilitating managerial

71. Jevic, 137 S. Ct. at 985

72. Professor LoPucki has two books and numerous articles on the issue. See generally LyNN LoPucki, Courting Failure (2005); Lynn LoPucki \& Joseph Doherty, Professional Fees in Corporate Bankruptcies: Data, Analysis and Evaluation (2011); Lynn M. LoPucki \& Sara D. Kalin, The Failure of Public Company Bankruptcies in Delaware and New York: Empirical Evidence of a "Race to the Bottom," 54 VAND. L. REV. 231, 232-37 (2001).

73. Stephen J. Lubben, American Bankruptcy Institute Chapter 11 Fee Study (Seton Hall Pub. Law Research Paper No. 1020477, 2007); Stephen J. Lubben, Chapter 11 as Intrigue: A Review of LoPucki. and Doherty's Professional Fees in Corporate Bankruptcies, 28 BANking \& FIN. L. REV. (Canada) 171 (2012); Stephen J. Lubben, What We "Know" About Chapter 11 Cost Is Wrong, 17 FordHAM J. CoRP. \& FIN. L. 141 (2012); Stephen J. Lubben, Professional Fees in Corporate Bankruptcies: Data, Analysis and Evaluation, ABI J., Apr. 2011, at 60; Stephen J. Lubben, Corporate Reorganization \& Professional. Fees, 82 Am. Bankr. L.J. 77 (2008); see also David A. Skeel, Jr., Lockups and Delaware Venue in Corporate Law and Bankruptcy, 68 U. Cin. L. Rev. 1243 (2000) (competition beneficial); Barry E. Adler \& Henry N. Butler, On the "Delawarization of Bankruptcy" Debate, 52 Emory L.J. 1309 (2003) (downplaying importance of observed jurisdictional competition in U.S. bankruptcy); Marcus Cole, "Delaware Is Not a State": Are We Witnessing Jurisdictional Competition in Bankruptcy?, 55 VAND. L. REV. 1845 (2002). 
overreach ${ }^{74}$ ) or a race to the top (i.e., is desirably producing efficient governance $^{75}$ and speedy litigation ${ }^{76}$ ). Again, juxtaposing the corporate law development, the Supreme Court had the opportunity in Santa Fe Industries, Inc. v. Green to let federal securities law supplant a significant fraction of state corporate law by allowing securities fraud to address practices covered by state fiduciary obligations, but it refused to do so. ${ }^{77}$

The Jevic facts offered the court an opportunity to address this debate explicitly, and perhaps it did implicitly. The court could have addressed fees explicitly by noting that the settlement produced funds that would pay the bankruptcy professionals, whereas the alternative of a straight dismissal would not. If the settlement was not approved, and the administrative insolvency led to a straight dismissal, that would produce the possibility of other lawyers pursuing the employees' reinstated fraudulent transfer claims. Thus, the suspicion may be created that the structured dismissal was colored by the bankruptcy court's generosity toward the bankruptcy professionals. If the Supreme Court was strongly concerned about this attitude regarding fees, then the court, noting this dynamic, may have expressly imposed higher standards in settings where a bankruptcy court's generosity regarding fees might create bias. Granted, the issue was not raised by either the litigants or any of the amici, but the Supreme Court could have moved in that direction, and it did not. Akin to not interfering with the equivalent corporate law issue, the Supreme Court refrained from expressly intervening on these facts. However, the Supreme Court's opinion could also be interpreted as being consistent with a skeptical attitude about generosity toward fees because it disapproved of the result. This also means that the opinion did not have to also address concerns about fees. For practice, the cautious course may be to point out these tensions to the court when seeking approvals of transactions that raise issues about generosity toward fee applications so that the court may address the tension explicitly.

74. See, e.g., Lucian Arye Bebchuk, Federalism and the Corporation: The Desirable Limits on State Competition in Corporate Law, 105 Harv. L. Rev. 1435 (1992); William L. Cary, Federalism and Corporate Law: Reflections Upon Delaware, 83 YALE L.J. 663 (1974); Melvin Aron Eisenberg, The Structure of Corporation Law, 89 Colum. L. Rev. 1461 (1989); see also Michael Klausner, Corporations, Corporate Law, and Networks of Contracts, 81 VA. L. REv. 757 (1995).

75. See, e.g., Robert Daines, Does Delaware Law Improve Firm Value?, 62 J. FIn. Econ. 525 (2001); Peter Dodd \& Richard Leftwich, The Market for Corporate Charters: "Unhealthy Competition" Versus Federal Regulation, 53 J. Bu5. 259 (1980); Daniel R. Fischel, The "Race to the Bottom" Revisited: Reflections on Recent Developments in Delaware's Corporation Law, 76 Nw. U. L. REv. 913 (1982); Roberta Romano, Law as a Product: Some Pieces of the Incorporation Puzzle, 1 J.L. ECoN. \& ORG. 225 (1985); Ralph K. Winter, Jr., State Law, Shareholder Protection, and the Theory of the Corporation, 6 J. LEGAL STuD. 251 (1977).

76. The Delaware Supreme Court itself points out the standard of expeditiousness that its openness to emergency trials and appeals sets: A takeover defense instituted on April 17 and challenged on the same day produced a temporary restraining order on April 29 and, after a hearing, certification of its appealability on May 14. The Supreme Court of Delaware accepted the case the same day, "received excellent briefs from the parties, heard argument on May 16 and announced [its] oral ruling in open court at 9:00 a.m. on May 17." Unocal Corp. v. Mesa Petroleum Co., 493 A.2d 946, $953 \&$ n.5 (Del. 1985).

77. 430 U.S. 462 (1977) (refusing to impose securities fraud liability on conduct that corresponded to violations of state corporate fiduciary obligations). 


\section{Settlement Propriety}

The Jevic opinion, on the surface, did not touch on settlement incentives. However, by juxtaposing Iridium, the opinion makes the distinguishing of the two settlements necessary, which this subpart does. That distinction rests on the corresponding incentives, which raise issues that the subsequent subpart explores. The distortion of settlement incentives due to fees has a rich trail of scholarship. ${ }^{78}$ This agency cost problem gets more pronounced in the triangular setting of settlements in bankruptcy, like those of Iridium or Jevic.

A stylized version of the Iridium facts illustrates the problem. Suppose that the unsecured creditors have a 60 percent chance of avoiding a lien of Chase in assets of the debtor worth $\$ 140$ and a 20 percent chance of imposing liability on Motorola for mismanagement and breach of contract, in which case, Motorola would be liable for $\$ 2,500$. Outside of bankruptcy, to Iridium itself, those claims would be worth, respectively, about $\$ 84$ (60 percent of $\$ 140$ ) and $\$ 500$ (20 percent of $\$ 2,500$ ) assuming Iridium was neutral toward risk. ${ }^{79}$ The claims would produce mirror images for the corresponding obligors, being worth a loss of $\$ 84$ to Chase and of $\$ 500$ to Motorola. This produces a relatively narrow range of values where a settlement could be reached for each claim. The addition of legal fees that do not shift to the loser widens the settlement range. ${ }^{80}$ The example is based on extrapolations from the actual numbers in Iridium, in millions. ${ }^{81}$

In bankruptcy, however, a settlement with Chase that finances the litigation against Motorola has numerous additional consequences. Focus, first, ${ }^{82}$ on that,

78. This research has two main strands, one on the effect of contingent fees on settlements and one on the effect of the award of attorney's fees ("British rule"). See, e.g., Keith N. Hylton, An Asymmetric-Information Model of Litigation, 22 InI'L REv. L. \& ECON. 153 (2002); Steven Shavell, Suit, Settlement, and Trial: A Theoretical Analysis Under Alternative Methods for the Allocation of Legal Costs, 11 J. Legal Stud. 55 (1982); Gordon Tullock, Trials on Trial: The Pure Theory of Legal ProCEDure (1980); see also Lucian Arye Bebchuk, A New Theory Concerning the Credibility and Success of Threats to Sue, 25 J. Legal Stud. 1 (1996); Ronald Braeutigam, Bruce Owen \& John Panzar, An Economic Analysis of Alternative Fee Shifting Systems, 47 L. \& ConTEMP. Probs. 173 (1984); Lester Brickman, ABA Regulation of Contingency Fees: Money Talks, Ethics Walks, 65 FoRDHAM L. REv. 247 (1996); Jonathan Fischbach \& Michael Fischbach, Rethinking Optimality in Tort Litigation: The Promise of Reverse Cost-Shifting, 19 BYU J. Pub. L. 317, 320 (2005); Adam Shajnfeld, A Critical Survey of the Law, Ethics, and Economics of Attorney Contingent Fee Arrangements, 54 N.Y.L. ScH. L. REv. 773 (2010); Note, Fee Shifting: Perspectives for EAJA Reformers, 28 J.L. \& PoL. 371 (2013).

79. If Iridium and the other parties were averse toward risk then uncertain claims are worth a little less and uncertain obligations are worth a little more (again a little less if they are seen as negative numbers). The example will continue assuming risk-neutrality without repeating these caveats.

80. See Steven Shavell, Suit, Settlement, and Trial: A Theoretical Analysis Under Alternative Methods for the Allocation of Legal Costs, 11 J. LEGAL STUD. 55 (1982); see also supra note 78.

81. The settlement with Chase funded $\$ 42.5$ million of fees, $\$ 37.5$ million for the litigation against Motorola and $\$ 5$ million in general fees and provided no other direct payments. The unsecured creditors sought to invalidate as avoidable preferences transfers of about $\$ 140$ million into bank accounts that were collateral for Chase ( 90 percent of transfers into accounts of size about $\$ 156$ million). The claim against Motorola was worth "billions" and is here estimated at $\$ 2.5$ billion from the fact that Iridium entered bankruptcy with debts of about $\$ 4$ billion after having recently borrowed $\$ 1.55$ billion from Chase by pledging all its assets as collateral. See In re Iridium Operating LLC, 478 F. $3 d$ 452, 456-61 (2d Cir. 2007).

82. A second interesting curiosity of the settlement, to be discussed in the next subpart, was that the litigation that it financed was pursued by the committee of unsecured creditors. Yet, any recov- 
by financing the litigation against Motorola, the settlement likely raises the probability of a victory. Suppose the probability of a victory increases by 5 percent. This effect means that a settlement with Chase also produces a gain of $\$ 125$ (5 percent of $\$ 2,500)$ to the value of the claim against Motorola. Suppose the legal fees that the settlement funds are $\$ 42.5$. This means that the estate of Iridium sees an advantage to settling the litigation against Chase at any value above $\$ 1.5$ (the $\$ 84$ initial value of the claim reduced by the gain of $\$ 125$ in the value of the claim against Motorola and then increased by the $\$ 42.5$ in legal fees that Chase must pay). From Chase's perspective, the settlement range increases in a favorable direction. A claim that would previously seem destined for trial or settlement with Chase paying about $\$ 84$ now has a settlement range from Chase paying $\$ 1.5$ to Chase paying $\$ 84$. Whereas these numbers give the impression that this phenomenon is a result of the large size of the claim against Motorola, it can also arise with a smaller claim, if the probability of prevailing changes more from the funding of the litigation. ${ }^{83}$

The point is that the triangular dynamic makes the estate willing to settle against Chase with terms agreeable to Chase to strengthen the estate's position against Motorola. If Motorola settled at the new increased value for the estate of the claim, then the estate would have gained significantly. However, Motorola chose to litigate. After a very lengthy trial on only the issue of undercapitalization, Motorola prevailed. ${ }^{84}$ The remaining counts against Motorola were dismissed as part of a final global settlement a few months later. ${ }^{85}$

eries that the litigation would bring would accrue 37.5 percent to Chase according to the settlement terms, and the remaining 62.5 percent that would go to the estate would in large part go to Motorola, as an administrative creditor. Thus, the greatest economic interest opposite Motorola was that of Chase but the litigation was directed by the unsecured creditors' committee. Iridium, 478 F.3d at 459 ("The Lenders [led by Chase] would take 37.5 percent of any recovery. The other 62.5 percent of the recovery would go to the Estate, to be distributed according to a future, as-yet-unconfirmed reorganization plan, with administrative creditors—such as Motorola—taking first.").

83. For instance, the example would remain unchanged if the claim against Motorola were $\$ 250$ and the funding of the litigation increased the chance of the debtor's success by 50 percent, giving the same $\$ 125$ gain for the estate from funding the litigation. Increasing the legal fees would narrow the settlement range.

84. The bankruptcy court stressed the extraordinary nature of the trial:

Following years of fact and expert discovery, pretrial motions and the submission of a final pretrial order, the parties, in consultation with the Court, consented to bifurcate the trial in order to streamline what otherwise would have been an unwieldy and prolonged proceeding. The first phase of the trial, by agreement, was limited to the questions of whether Iridium was insolvent or had unreasonably small capital during the four-year period prior to commencement of the bankruptcy case. Even with this agreement to limit the issues, this phase of the trial was unusually long-fifty trial days. Opening arguments took place on October 23, 2006; closing arguments were presented on June 5, 2007. Between the opening argument and the closing, 52 witnesses testified, including 7 experts, and 866 exhibits were admitted into evidence. The parties submitted detailed post-trial proposed findings of fact and conclusions of law and post-trial briefs.

In re Iridium Operating LLC, No. 99-45005, slip op. at 3 (S.D.N.Y. Bankr. Aug. 31, 2007) (Opinion Regarding Insolvency and Unreasonably Small Capital) [archived at https://perma.cc/6JXE-ZGDL].

85. In re Iridium Operating LLC, No. $99-45005$ (S.D.N.Y. Bankr. May 20, 2008) (Order Pursuant to Sec. 105, 362 and 363 of the Bankruptcy Code and Bankr. Rule 9019 Approving a Global Settlement of Disputes Between and/or among the Debtors, the Statutory Committee of Unsecured Cred- 
The dynamics of the Jevic settlement had a sharp difference. Instead of the settlement producing an opportunity to enlarge the estate and recoveries, the settlement sought to reduce those opportunities for the employees. The employees were pursuing litigation in an attempt to impose liability on the acquirer, Sun, for the failure of the debtor to give adequate notice of its mass layoffs according to the WARN Act. The committee of unsecured creditors settled the LBO fraudulent transfer claims against Sun and CIT, but Sun did not want that settlement to finance the employees' WARN Act litigation against Sun. Therefore, Sun sought to exclude the employees from the proceeds of the settlement. The proceeds of the settlement also paid the legal fees, and because the case was ripe for dismissal, the court entered the structured dismissal order, which also precluded the employees from pursuing Sun and CIT under fraudulent transfer theories. Rather than funding a project to enlarge the estate, the settlement avoided funding the employees' litigation. ${ }^{86}$

If the Supreme Court had not allowed the question presented to change from propriety of settlements to propriety of structured dismissals, then the opinion would have addressed settlements and might have distinguished that of Jevic from that of Iridium. Nevertheless, the court offered approving dicta for the settlement of Iridium because it had the potential to enlarge the estate. ${ }^{87}$ Thus, the dicta of Jevic do distinguish the two settlements exactly on that issue. The settlement in Iridium had the advantage of financing a potential enlargement of the estate, which Jevic's did not. If a settlement entails priority violations, bankruptcy reasons must justify them, such as the opportunity to enlarge the estate that Iridium's settlement produced.

\section{Litigating and Settling Incentives}

This focus on Iridium reveals an additional complexity. Consider whether, in Iridium, the unsecured creditors' committee was the appropriate entity to pursue the litigation against Motorola. Because the secured creditor was Chase, and because Chase would gain from immediate increases in the value of the estate, one could think that the proper entity to pursue the litigation was Chase. However, focusing on the payout of the litigation suggests that the unsecured creditors' committee may well have been the correct entity to pursue the litigation. Granted, the litigation against Motorola may have had a low probability of suc-

itors, the Debtors' Prepetition Secured Lenders and Motorola, Inc.) [archived at https:/perma.co 28UJ-9HU8] ("dismissing the Motorola Litigation").

86. The other side of this asks if Sun and CIT truly were willing to settle the fraudulent transfer claims at their probability-adjusted value, was the consent of the employees necessary? The answer is no, as long as the proceeds of the settlement follow priorities. To avoid financing the employees' litigation, the amount that the employees would be entitled to receive could be made subject to a mechanism delaying its distribution, such as a trust.

87. Czyzewski v. Jevic Holding Corp., 137 S. Ct. 973, 985 (2017) (after distinguishing Iridium as an interim order rather than a final one, the opinion proceeds to stress what the Jevic settlement did not do, in an implicit juxtaposition to that of Iridium and proper first-day orders, including that the Jevic settlement "does not make the disfavored creditors better off; it does not promote the possibility of a confirmable plan"). 
cess, but it also had an enormous potential gain. Because the secured creditors would only experience a limited gain, they would not capture the marginal gains from the litigation and would be undermotivated to pursue it. Their incentives would only be to optimally produce the recovery that would cover their claim rather than the (potentially larger) optimal recovery. Incentives are appropriate for the entity that bears the marginal effect of decisions. The unsecured creditors could have the optimal litigation incentives if they experienced the gain in reaction to marginal adjustments in litigation strategy, to wit, the award increase from the marginal motion or objection.

This analysis also reveals that the unsecured creditors may not have had the appropriate incentives to settle the Motorola litigation, despite having the appropriate incentives to litigate it. If the probability of success was very low, then the probability-adjusted amount at which a settlement was reasonable could have not led to a payout for the unsecured creditors. Even if Motorola was willing to settle at the probability-adjusted value of the claim, that settlement might only produce a payout for Chase. The settlement, then, would be unappealing for the unsecured creditors.

Bankruptcy law is silent about the proper standards for evaluating this setting despite the fact that the equivalent setting in corporate law is known and addressed by a shift of fiduciary duties ${ }^{88}$ The silence of bankruptcy law is understandable because the Code envisions close supervision by the court that would make the decision. In addition, the stratification of the classes can mean that no class has the perfect incentives to settle, as was likely the case in Iridium. ${ }^{89} \mathrm{In}$ Jevic, the willingness of the unsecured creditors to settle should be suspect instead of being relied upon by the lower courts, because the settlement gave value to the unsecured creditors to which they would not be entitled according to priorities.

88. When the choice of the board of directors is between a risky course of action which, if successful, will benefit shareholders, but if unsuccessful will impose losses on creditors, and a safe course of action that does not produce gains for the shareholders, the board of directors in choosing must not promote the interests of shareholders alone, as fiduciary duties become broader. See, e.g., Geyer v. Irgensoll Publ'ns Co., 621 A.2d 784, 791 (Del. 1992) ("[T]he fact of insolvency ... causes fiduciary duties to creditors to arise."); In re NCS Healthcare, Inc., Sholders Litig., 825 A.2d 240, 256-57 (Del. Ch. 2002) (" $[\mathrm{A}] \mathrm{s}$ directors of a corporation in the 'zone of insolvency,' the NCS board members also owe fiduciary duties to the Company's creditors."); Credit Lyonnais Bank Nederland, N.V. v. Pathe Commc'ns Corp., Civ. A. No. 12150, 1991 WL 277613, at *34 (Del. Ch. Dec. 30, 1991) ("At least where a corporation is operating in the vicinity of insolvency, a board of directors is not merely the agent of the residue risk bearers, but owes its duty to the corporate enterprise.").

89. The unsecured creditors would not have had the incentive to settle if the settlement did not provide them with any payout, already discussed above. Neither the secured creditors, Chase, would have the proper incentives to settle. The secured creditors would settle too easily because they would only capture part of the upside from a trial. Using the numbers of the example, the probabilityadjusted value of the claim was 20 percent of $\$ 2,500$ or $\$ 500$. Therefore, a fair settlement should be in that neighborhood. Chase's secured claim was for only $\$ 1,550$, meaning that for Chase a victory only brings up to that amount (minus what Chase gets already on the basis of its security interests). Even if Chase were getting nothing on its security interests, Chase would be willing to accept any offer of Motorola to settle at above 20 percent of $\$ 1,550$ or $\$ 310$, rather than an offer close to $\$ 500$. The fact that in the Iridium settlement Chase accepted to limit the upside of its secured claim could mean that Chase would be willing to settle at terms much more favorable to Motorola. 
Moreover, the Buttner ${ }^{90}$ principle would argue that a settlement that would occur outside of bankruptcy should not be prevented by bankruptcy without a bankruptcy reason. Therefore, if Motorola were willing to settle the claim at about its probability-adjusted value, then the circumstances of bankruptcy should not stand in the way of a settlement. The procedures of bankruptcy must be sensitive to this. Outside bankruptcy, Motorola could at any moment during the trial decide to settle. In bankruptcy, however, Motorola's opponent was not an appropriate party with whom to settle. Thus, the court must at all moments be open to a settlement hearing at Motorola's request while being cognizant that Chase would likely support a settlement too easily, whereas the unsecured creditors would likely object even to a generous settlement.

\section{Conclusion}

This article went on a journey that was spurred by Jevic's "no" to structured dismissals. The sights on this journey were (a) the pending clarification of whether nonconsensual structured dismissals arise from individual creditor objections or only from the objection of a class; (b) the increased scrutiny on firstday orders, especially in liquidating reorganizations; (c) advised caution on potential biases from generosity about fees; (d) the continued propriety of interim approvals of settlements provided any priority violations are overcome by bankruptcy reasons, such as opportunities to enlarge the estate as in Iridium; and (e) that the class appropriate to litigate likely may not have the appropriate incentives to settle a dispute, but that the court should be open to a settlement.

Whereas at his closing at oral argument, Jevic's counsel warned against making the Bankruptcy Code into a "suicide pact," 91 the opinion's narrow holding certainly does not do so. By revealing these complexities, the door opens for further cautious refinement of reorganization law by the lower courts.

90. Butner v. United States, 440 U.S. 48 (1979) (not altering state law outcome absent a bankruptcy reason).

91. Jevic Transcript, supra note 28 , at 62 . 